\title{
Man-made Mediterranean temporary ponds as a tool for amphibian conservation
}

\author{
Albert Ruhí $^{1 *}$, Olatz San Sebastian ${ }^{2,3,4}$, Carles Feo ${ }^{1,5}$, Marc Franch ${ }^{2,3,4}$, Stéphanie Gascón ${ }^{1}$, \\ Àlex Richter-Boix ${ }^{2,6}$, Dani Boix ${ }^{1}$ and Gustavo Llorente ${ }^{2}$ \\ ${ }_{1}^{1}$ Institute of Aquatic Ecology, University of Girona, Girona, Catalonia, Spain \\ 2 Animal Biology Department, University of Barcelona, Barcelona, Catalonia, Spain \\ 3 Observatorio de Herpetología de Aranzadi, Donostia, Spain \\ ${ }^{4}$ Fundació Emys, Riudarenes, Catalonia, Spain \\ ${ }^{5}$ Museu Darder Espai d'interpretació de l'Estany, Banyoles, Catalonia, Spain \\ ${ }^{6}$ Department of Population Biology - Evolutionary Biology Centre, University of Uppsala, Uppsala, Sweden
}

Received 22 July 2011; Accepted 16 December 2011

\begin{abstract}
Mediterranean temporary ponds (MTPs) are crucial breeding sites for local amphibians, a faunal group in decline in the Mediterranean mainly due to wetland destruction. Although the disappearance of lentic habitats in other regions of the world has been ameliorated by the creation and restoration of wetlands, these tactics remain untested in Mediterranean wetlands. To evaluate the amphibian colonization dynamics of artificial MTPs in the north-eastern Iberian Peninsula, we monitored two artificial MTPs (one in a highdiversity area and the other in a low-diversity area) over 2 years. We selected reference wetlands at each area, and amphibian communities of man-made MTPs were compared to those of reference wetlands. We found that, beginning in the first year, artificial MTPs were a valuable habitat for regional amphibian fauna. Posteriorly, we focused on the reproductive success of the natterjack toad, Bufo calamita. Using a drift fence equipped with pit-fall traps, we measured the abundance of both reproductive adults entering the pond and post-metamorphic individuals exiting the pond. Using mark-recapture methods, we analyzed the time and energy costs associated with reproduction in the artificial MTPs. We observed a highly variable colonization dynamics between sites, between hydroperiods, and within hydroperiods, and these dynamics often depended on meteorological factors. Our results suggest that even at a short timescale, native amphibian species such as B. calamita can benefit from wetland creation in the Mediterranean region.
\end{abstract}

Key words: Mediterranean temporary ponds / wetland creation / conservation / amphibians / Bufo calamita

\section{Introduction}

Amphibians have suffered a recent serious global decline (Houlahan et al., 2000; Stuart et al., 2004; Beebee and Griffiths, 2005), and due to habitat reduction, pollution, pathogens and introduced predators, native amphibian species are facing a potential mass extinction (Wake and Vredenburg, 2008). In the Mediterranean region, wetland destruction is the main cause for amphibian decline, as $89 \%$ of the endangered species have suffered habitat loss (Cox et al., 2006). In this context, temporary ponds represent neglected habitats of vast biological value in the Mediterranean region (Boix et al., 2001; Grillas et al., 2004), providing essential breeding sites for amphibians (Jakob et al., 2003; Díaz-Paniagua

\footnotetext{
*Corresponding author: albert.ruhi@udg.edu
}

et al., 2010). Although the maintenance of Mediterranean temporary ponds (MTPs) as priority habitats is encouraged by the 92/43/CEE European Commission Habitats Directive, continuing increases in agriculture and urban development make MTP long-term preservation critical (Zacharias et al., 2007).

The global-scale process of assisting the recovery of degraded and damaged ecosystems (also known as ecological restoration) has been identified as one of the grand challenges to the Earth in the 21st century (Comín, 2010). In the USA, the 1989 federal goal of achieving "no overall net loss" of wetlands (Brown and Lant, 1999) partially addressed the progressive disappearance of lentic habitats through wetland creation and restoration. To evaluate how to lessen the effects of wetland loss on amphibian populations, studies have monitored both short-term (e.g., Perry et al., 1996; Lehtinen and 

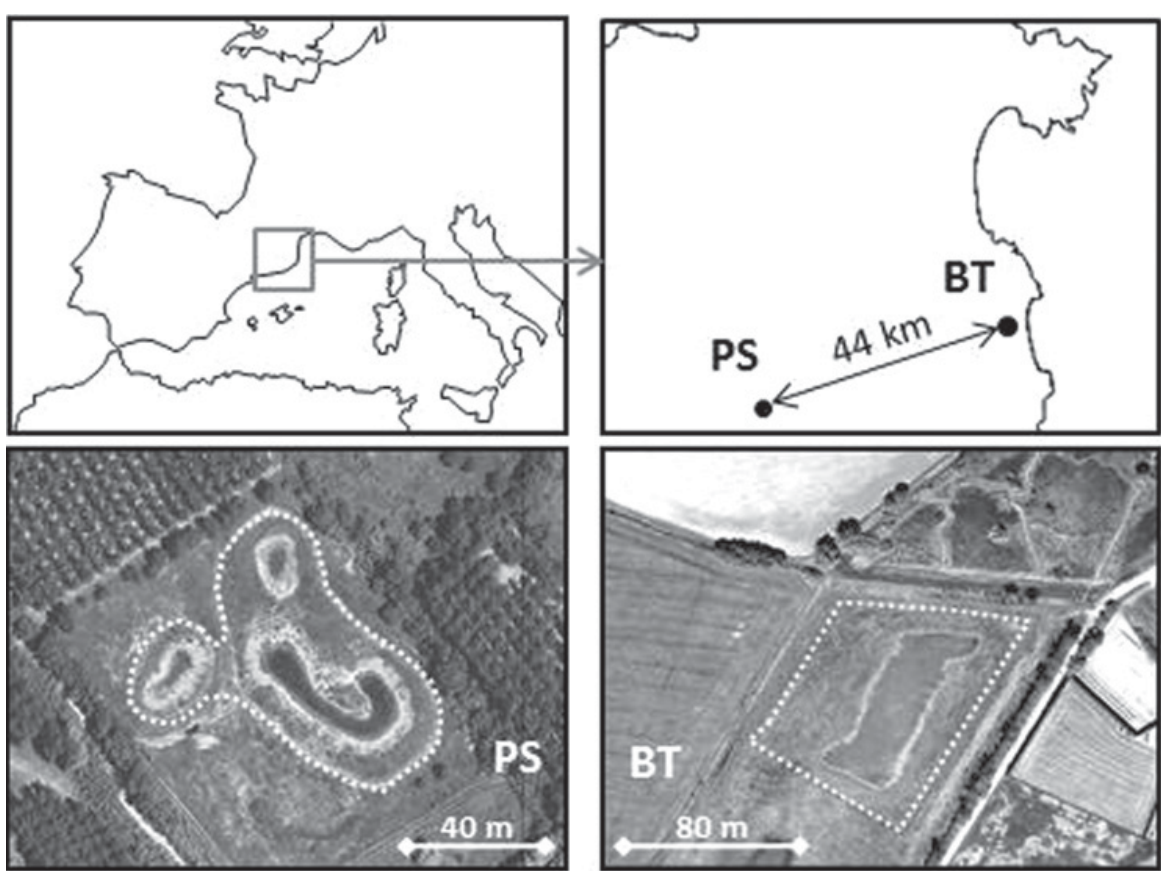

Fig. 1. Map of the study sites. Dashed lines represent the drift fences at each site.

Galatowitsch, 2001; Balcombe et al., 2005; Barry et al., 2008) and long-term (e.g., Pechmann et al., 2001; Petranka et al., 2003; Vasconcelos and Calhoun, 2006) colonization patterns and restoration effects. These studies revealed that the timescale of operation for the newly created or restored wetland is critical, as temporal population responses and environmental stressors determine which species are likely to benefit from the wetlands (Petranka et al., 2007).

Many European studies have also demonstrated the conservation value of temporary wetlands (Oertli et al., 2005), particularly for amphibians (Laan and Verboom, 1990; Jeffries, 1991; Joly and Grolet, 1996; Beebee, 1997; Stumpel and van der Voet, 1998; Baker and Halliday, 1999; Rannap et al., 2009; Lesbarrères et al., 2010). However, the creation and restoration of MTPs in the Mediterranean region are still very rare. Although there is some information about invertebrate colonization of these restored wetlands (e.g., Ruhí et al., 2009), there are few data that describe amphibian colonization of newly created MTPs. New wetlands are often designed to replace natural wetlands within short time periods (i.e., Pechmann et al., 2001; Lesbarrères et al., 2010) despite associated controversy (Mitsch and Wilson, 1996). Therefore, it will be crucial to determine if species of high conservation concern can colonize artificial MTPs within these brief periods. Moreover, quantifying the productivity of these MTPs will provide an estimate of how well creating new aquatic habitats maintains local biodiversity (Gibbons et al., 2006).

Here, we investigated amphibian colonization and reproduction in two artificial MTPs over a 2-year period. Specifically, we (i) determined which amphibian species could colonize artificial MTPs within a short-term period, (ii) compared the community established in the man-made MTP to that of nearby reference wetlands and (iii) studied the colonization dynamics and assessed the reproductive success of a species of conservation concern, the natterjack toad Bufo calamita (Laurenti, 1768), in the newly created MTP.

\section{Materials and methods}

\section{Study sites}

The artificial MTPs are located in two lowland areas of the NE Iberian Peninsula: Baix Ter and Plana de la Selva (Fig. 1). In the summer of 2006, arable lands at these sites were transformed into human-made wetlands (BT and PS, respectively), which were flooded in September 2006. Both newly created wetlands were excavated from lacustrine silty clays. Both wetlands covered $<0.5$ ha and were $<1$ m deep. BT was $<200 \mathrm{~m}$ from the Ter Vell wetlands, a pond-marsh-pond system under marine influence, and PS was $<200 \mathrm{~m}$ from the Esplet temporary stream and some natural temporary and permanent ponds. For both sites there already existed some information about amphibian assemblages, being BT a low-diversity area, with five species, and PS a high-diversity area, with 11 (Pleguezuelos et al., 2002; Boix et al., 2004a). At both sites, nearby riparian vegetation was dominated by alders (Alnus glutinosa), poplars (Populus nigra), willows (Salix alba), ashes (Fraxinus angustifolia) and elms (Ulmus minor). Aquatic vegetation was not planted within the wetlands, but within the first year of the study, charophytes had colonized both wetlands. By the second year, macrophytes, such as the common reed (Phragmites australis), 


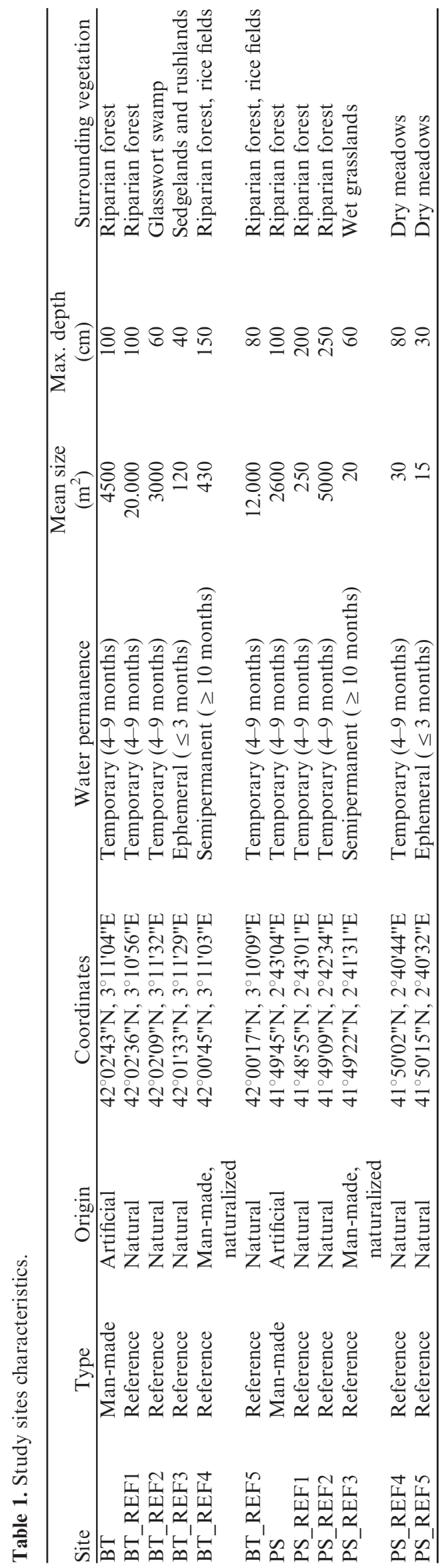

bullrush (Typha latifolia) and water plantain (Alisma plantago-aquatica), had also appeared in both wetlands. The Estat de Conservació d'Ecosistemes Lenítics Soms (Shallow Lentic Ecosystem Conservation Status) (ECELS) index (Sala et al., 2004), which characterizes the conservation status of a wetland in terms of (i) basin littoral morphology, (ii) human activity, (iii) water characteristics, (iv) emergent vegetation and (v) hydrophytic vegetation, provided high punctuations for most of the components in both sites (PS, 97 out of 100 points; BT, 79 out of 100 points). Human activity in BT lowered the value of the index, mainly due to influence of intensive agriculture.

In order to gather information about the local amphibian community, 10 existing reference wetlands were selected, five in each area (Fig. 1, Tab. 1). These wetlands were located within a $3 \mathrm{~km}$ range of the respective man-made MTPs. Different types of reference wetlands were selected in order to encompass the natural variability of the existing waterbodies. Thus, at each site, one out of the five was a semipermanent (hydroperiod $\geq 10$ months) naturalized man-made wetland, three were natural MTPs similar to the man-made ones (hydroperiod 4-9 months) and one was an ephemeral pool (hydroperiod $\leq 3$ months).

\section{Sampling and sample processing}

\section{Man-made MTPs}

In BT and PS, every month from September 2006 to September 2008 we measured water conductivity using a Crison 524 conductivity meter, dissolved oxygen using a Hach HQ10 Portable LDO meter and water level using a graduated gauge. On each sampling visit, water samples were collected, filtered through $\mathrm{GF} / \mathrm{C}$ Whatman filters, and frozen in the laboratory. We analyzed the dissolved inorganic nutrient content (ammonium, $\mathrm{NH}_{4}^{+}$; nitrite, $\mathrm{NO}_{2}^{-}$; nitrate, $\mathrm{NO}_{3}^{-}$; and soluble reactive phosphorus, $\mathrm{PO}_{4}^{3+}$ ) of the filtered samples according to Grasshoff et al. (1983).

Amphibian larvae were sampled monthly using a dip net (250 $\mu \mathrm{m}$ mesh; $20 \mathrm{~cm}$ in diameter). To capture all types of the macrofaunal community, we swept the dip net 20 times in rapid sequence, covering all different microhabitats. Amphibian larvae were sorted, identified and measured in the laboratory.

Within the two hydroperiods (September 2006 to August 2007 and September 2007 to August 2008) we surveyed post-metamorphic and adult amphibians during two intervals (Fig. 2): interval 1 was from March 29, 2007 to June 12, 2007 and interval 2 was from March 12, 2008 to June 28,2008 . For these surveys, $10 \mathrm{~cm}$ of a $50-\mathrm{cm}$ tall plastic drift fence was buried, completely encircling the pond. Outside and inside of the fence, pitfall traps $(30 \mathrm{~cm}$ in diameter and $40 \mathrm{~cm}$ deep) were located every $15 \mathrm{~m}$. Each trap was equipped with a funnel to prevent trapped climbing species from escaping. To avoid desiccation in the trap, a lid above the entrance reduced insolation, and a 


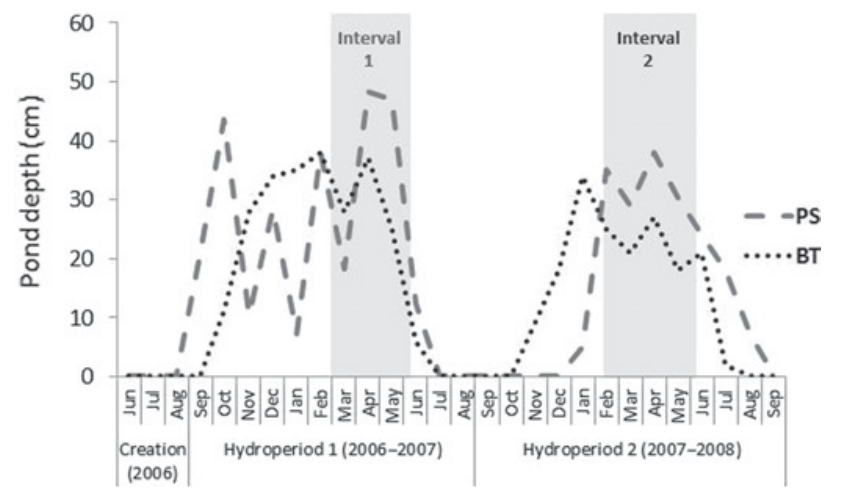

Fig. 2. Hydrological regime of BT and PS. The water levels are shown by dotted and dashed lines. The intervals for the pit-fall experiments are shown in gray.

wet sponge inside the trap reduced dryness. Traps were checked every other day, being from both sites visited on the same day. From April 11, 2007 to April 28, 2007, area floods decreased the trapping efficiency in BT. For each capture, we recorded species, sex, weight $( \pm 0.01 \mathrm{~g})$, length (snout-vent length) $(\mathrm{SVL} \pm 0.1 \mathrm{~mm})$ and released the animal on the opposite side of the fence. Additionally, in interval 2, we individually marked $B$. calamita adults using a toe-clipping technique (Donnelly et al., 1994). For each marked individual, we measured the number of times it entered and exited the wetland within the interval, the time (in days) that it spent inside the wetland, and the amount of weight lost during reproduction. During interval 1 and interval 2, precipitation and minimum and maximum daily temperature data were collected from nearby Catalan Meteorological Service (SMC-Meteocat) stations.

\section{Reference wetlands}

In order to know the local amphibian community, all reference wetlands were surveyed during the year previous to the study. They received four visits, two in autumn (September-November) and two in spring (March-May). At each visit, two sampling procedures were applied. On the one hand, larvae were captured dip-netting, using the same sampling methodology as in man-made MTPs. On the other hand, nocturnal transects (sensu Pearman et al., 1995) provided data on singing adults that would have been hardly detected otherwise.

\section{Data analysis}

In order to compare the extent to which the man-made MTP community of the first and second hydroperiod was similar to the amphibian community inhabiting the reference wetlands at each site, we performed an analysis of similarities (ANOSIM) test. This type of test operates on a resemblance matrix and is similar to a standard univariate analysis of variance (ANOVA), but requires neither the normality nor homoscedasticity of data. Wetland type was selected as factor in the simple layout of this test, using the species presence/absence matrix. The distance matrix was built with the Bray-Curtis similarity measure, and the results showed a global $R$ - and $P$-value expressed as a percentage. Besides, a similarity of percentages analysis (SIMPER) identified those species which characterized the community of each wetland type, ordering the species from more to less contribution to the total within-type similarity (cut-off for low contributions at $70 \%$ ). A full description of SIMPER analysis is provided by Clarke (1993).

Spearman non-parametric correlation tests allowed analyzing if the daily number of $B$. calamita adults entering the wetlands or the daily number of postmetamorphic individuals exiting the wetlands were correlated to meteorological data (precipitation, maximum daily temperature and minimum daily temperature). To account for the every-other-day sampling pattern, precipitation data were given as the cumulative precipitation over the 2 days, and temperature data were averaged over the 2 days. Using a Generalized Linear Mixed Model (GLMM), we set the response variable as the number of captured individuals per day, the tested factors were site (BT vs. PS), interval (interval 1 vs. interval 2) and week (1-16), set out as fixed effects, and sampling day was set as a random factor to account for temporal pseudoreplication. In mixed models, random effects deal with pseudoreplication by modeling the covariance structure introduced in the random part of the model (Crawley, 2002). We started with a model without interactions. Since the validation of the model showed no significant patterns in the residuals, interactions were not included. All matrices were log-transformed for a better fit of errors to a normal distribution.

Using ANOVA, we tested for site and sex effects on mobility (number of recaptures), time (number of days spent in the wetland) and reproduction cost (pre- and postreproduction difference in weight).

ANOSIM and SIMPER routines were performed using Primer (v. 6.0 for Windows, PRIMER-E, Plymouth); Spearman correlation tests, GLMM and ANOVA were performed using the software package PASW (v. 18, SPSS Inc., Chicago).

\section{Results}

\section{Characterization of BT and PS}

BT and PS had similar average temperatures, but PS had a wider temperature range (Tab. 2). Average precipitation was higher in PS. The hydrological regime was similar, with both sites exhibiting level oscillations despite the shallow mean depth $(11.7 \mathrm{~cm}$ for BT and $23.2 \mathrm{~cm}$ for PS) and hydroperiods of 7-9 months (Fig. 2).

On the other hand, the surveys in the reference wetlands provided current information on the local existing amphibian communities. Five species were detected in BT reference wetlands (Discoglossus pictus, B. calamita, Hyla meridionalis, Pelophylax perezi and 
Table 2. Water and meteorological variables for BT and PS sites during two hydroperiods. For water variables, mean values (in bold) and standard deviation (in italics) are shown. Water variables: Ox., dissolved oxygen saturation; Cond., conductivity, Depth, average depth of the water column; DIN, concentration of dissolved inorganic nitrogen; SRP, concentration of soluble reactive phosphorus. For meteorological variables, cumulative precipitation during the study (in bold) and the range of monthly average minimum-maximum values (in italics) are shown. The average temperature during the study (in bold) and the range of monthly average minimum-maximum values (in italics) are shown. Meteorological variables: Rain, cumulative precipitation and monthly average minimum-maximum values; $T$, average temperature and monthly average minimum-maximum values.

\begin{tabular}{|c|c|c|c|c|c|c|c|c|}
\hline \multirow[b]{2}{*}{ Site } & \multirow[b]{2}{*}{ Hydroperiod } & \multicolumn{5}{|c|}{ Water variables } & \multicolumn{2}{|c|}{ Meteorological variables } \\
\hline & & $\overline{\text { Ox. }(\%)}$ & Cond. $\left(\mu \mathrm{S} . \mathrm{cm}^{-1}\right)$ & Depth $(\mathrm{cm})$ & DIN (mg.l $\left.{ }^{-1}\right)$ & SRP (mg. $\left.1^{-1}\right)$ & Rain (mm) & $T\left({ }^{\circ} \mathrm{C}\right)$ \\
\hline \multirow[t]{4}{*}{$\overline{\mathrm{BT}}$} & 1 & 92.7 & 2005.9 & 19.3 & 0.084 & 0.011 & 164 & 15.7 \\
\hline & & 18.6 & 497.1 & 15.7 & 0.139 & 0.042 & $2-93$ & $9.0-24.9$ \\
\hline & 2 & 85.9 & 3742.5 & 11.7 & 0.103 & 0.002 & 149 & 14.4 \\
\hline & & 13.1 & 2489.0 & 12.2 & 0.087 & 0.002 & $13-54$ & $8.9-24.2$ \\
\hline \multirow[t]{4}{*}{ PS } & 1 & 77.2 & 143.1 & 23.2 & 0.100 & 0.007 & 302 & 14.2 \\
\hline & & 21.2 & 200.9 & 19.0 & 0.067 & 0.011 & $23-101$ & $1.7-26.6$ \\
\hline & 2 & 87.1 & 114.9 & 12.0 & 0.067 & 0.009 & 420 & 14.0 \\
\hline & & 11.4 & 74.7 & 16.5 & 0.023 & 0.005 & $61-169$ & $2.2-25.7$ \\
\hline
\end{tabular}

Pelobates cultripes), whereas PS reference wetlands community consisted of these five species and six additional species (Salamandra salamandra, Lissotriton helveticus, Triturus marmoratus, Alytes obstetricans, Pelodytes punctatus and Bufo bufo).

\section{Man-made MTPs - reference wetlands community comparison}

The ANOSIM test showed a global significant effect of wetland type over the amphibian community $(R=0.458$, $P \leq 0.01)$, with significantly different compositions between BT and PS reference wetlands $(R=0.718, P \leq 0.01)$. In both sites, the respective man-made MTP community was similar to that inhabiting the reference wetlands, both during the first hydroperiod (BT: $R=0.12, P \geq 0.05$; PS: $R=-0.12, P \geq 0.05)$ and the second one (BT: $R=0.12$, $P \geq 0.05$; PS: $R=-0.02, P \geq 0.05)$. The SIMPER routine identified five species characterizing PS reference communities (B. calamita, D. pictus, H. meridionalis, $P$. punctatus and $P$. perezi), whereas only one species was identified in reference communities of BT (B. calamita). Higher species richness levels were achieved in man-made MTPs in BT than in the reference wetlands, both for larvae and adults and during both hydroperiods. On the contrary, species richness levels in PS fell within the reference wetlands margins, both for larvae and adults, throughout the study (Fig. 3).

\section{Colonization of the man-made MTPs}

In both sites, all species that were detected in hydroperiod 1 were also present during hydroperiod 2, being the most abundant $B$. calamita $(95 \%$ of the total captures in BT, $74 \%$ in PS). In BT, three of the five local amphibian species were successfully reproducing in the new wetland during hydroperiod 1. The fourth local species, $H$. meridionalis, arrived at hydroperiod 1

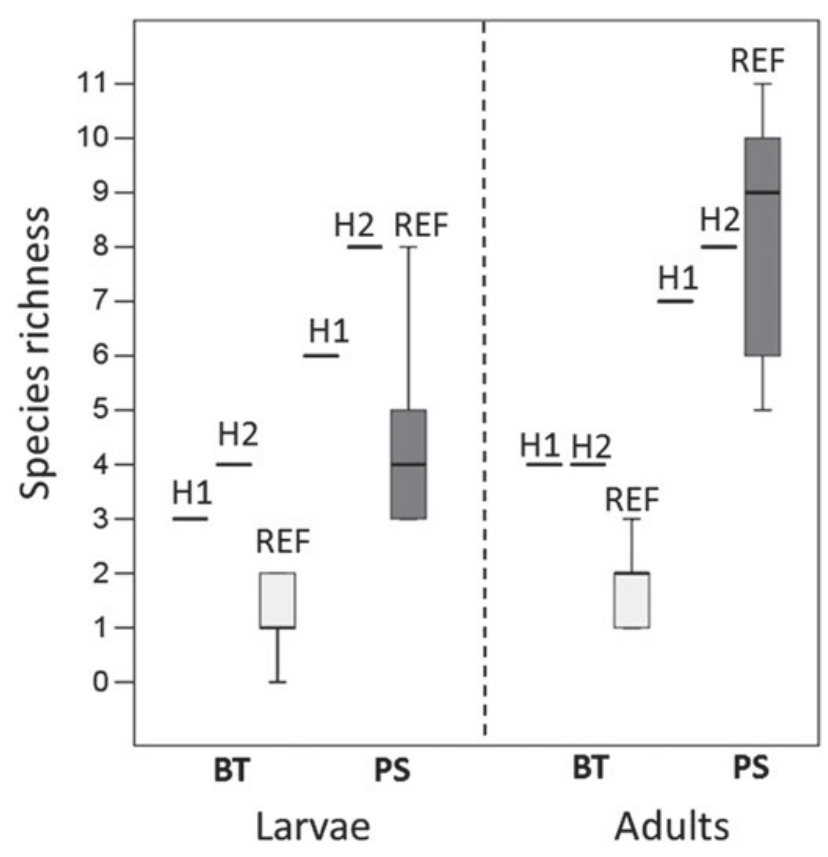

Fig. 3. Comparison of the species richness detected in the studied man-made MTPs (BT and PS) and the reference wetlands. H1, 1st hydroperiod of the studied man-made MTPs; H2, 2nd hydroperiod of the studied man-made MTPs; REF, reference wetlands at each site.

but did not reproduce until hydroperiod 2, and $P$. cultripes was never recorded (Tab. 3). Besides, in PS, six of the 11 local amphibian species reproduced in the wetland during hydroperiod 1 . In addition, two extra species reproduced there during hydroperiod 2: T. marmoratus arrived to PS as an adult at hydroperiod 1 but did not reproduce there until hydroperiod 2 , and L. helveticus was detected and reproduced during hydroperiod 2 . Although B. bufo adults were caught at PS during both hydroperiods, there was no evidence that they reproduced. $P$. perezi and $P$. cultripes were never detected in PS (Tab. 3). 
Table 3. Life cycle stage of amphibians captured at BT and PS during the study. L, larvae; M, individuals in post-metamorphic stage; A, adults.

\begin{tabular}{|c|c|c|c|c|c|c|c|c|c|c|c|c|c|c|}
\hline \multirow[b]{3}{*}{ Species } & \multicolumn{7}{|c|}{ BT } & \multicolumn{7}{|c|}{ PS } \\
\hline & \multirow[b]{2}{*}{ Locally present } & \multicolumn{3}{|c|}{ Hyd. 1} & \multicolumn{3}{|c|}{ Hyd. 2} & \multirow[b]{2}{*}{ Locally present } & \multicolumn{3}{|c|}{ Hyd. 1} & \multicolumn{3}{|c|}{ Hyd. 2} \\
\hline & & $\overline{\mathrm{L}}$ & $\mathrm{M}$ & $\overline{\mathrm{A}}$ & $\overline{\mathrm{L}}$ & $\mathrm{M}$ & $\overline{\mathrm{A}}$ & & $\mathrm{L}$ & $\mathrm{M}$ & $\overline{\mathrm{A}}$ & $\mathrm{L}$ & $\mathrm{M}$ & $\overline{\mathrm{A}}$ \\
\hline S. salamandra & - & - & - & - & - & - & - & Yes & 0 & 19 & 5 & 0 & 3 & $\gamma$ \\
\hline L. helveticus & - & - & - & - & - & - & - & Yes & 0 & 0 & 0 & 0 & 1 & 1 \\
\hline T. marmoratus & - & - & - & - & - & - & - & Yes & 0 & 0 & 2 & 0 & 1 & 1 \\
\hline D. pictus & Yes & 0 & 29 & 4 & 0 & 85 & 9 & Yes & 2 & 4 & 16 & 124 & 309 & 48 \\
\hline A. obstetricans & - & - & - & - & - & - & - & Yes & 0 & 6 & 3 & 0 & 1 & 0 \\
\hline P. punctatus & - & - & - & - & - & - & - & Yes & 0 & 2 & 1 & 0 & 1 & 3 \\
\hline B. bufo & - & - & - & - & - & - & - & Yes & 0 & 0 & 4 & 0 & 0 & 2 \\
\hline B. calamita & Yes & 0 & 2629 & 14 & 6 & 234 & 509 & Yes & 127 & 10 & 780 & 102 & 316 & 432 \\
\hline H. meridionalis & Yes & 0 & 0 & 1 & 14 & 0 & 3 & Yes & 5 & 0 & 0 & 20 & 18 & 2 \\
\hline P. perezi & Yes & 0 & 2 & 13 & 0 & 2 & 2 & Yes & 0 & 0 & 0 & 0 & 0 & 0 \\
\hline P. cultripes & Yes & 0 & 0 & 0 & 0 & 0 & 0 & Yes & 0 & 0 & 0 & 0 & 0 & 0 \\
\hline
\end{tabular}
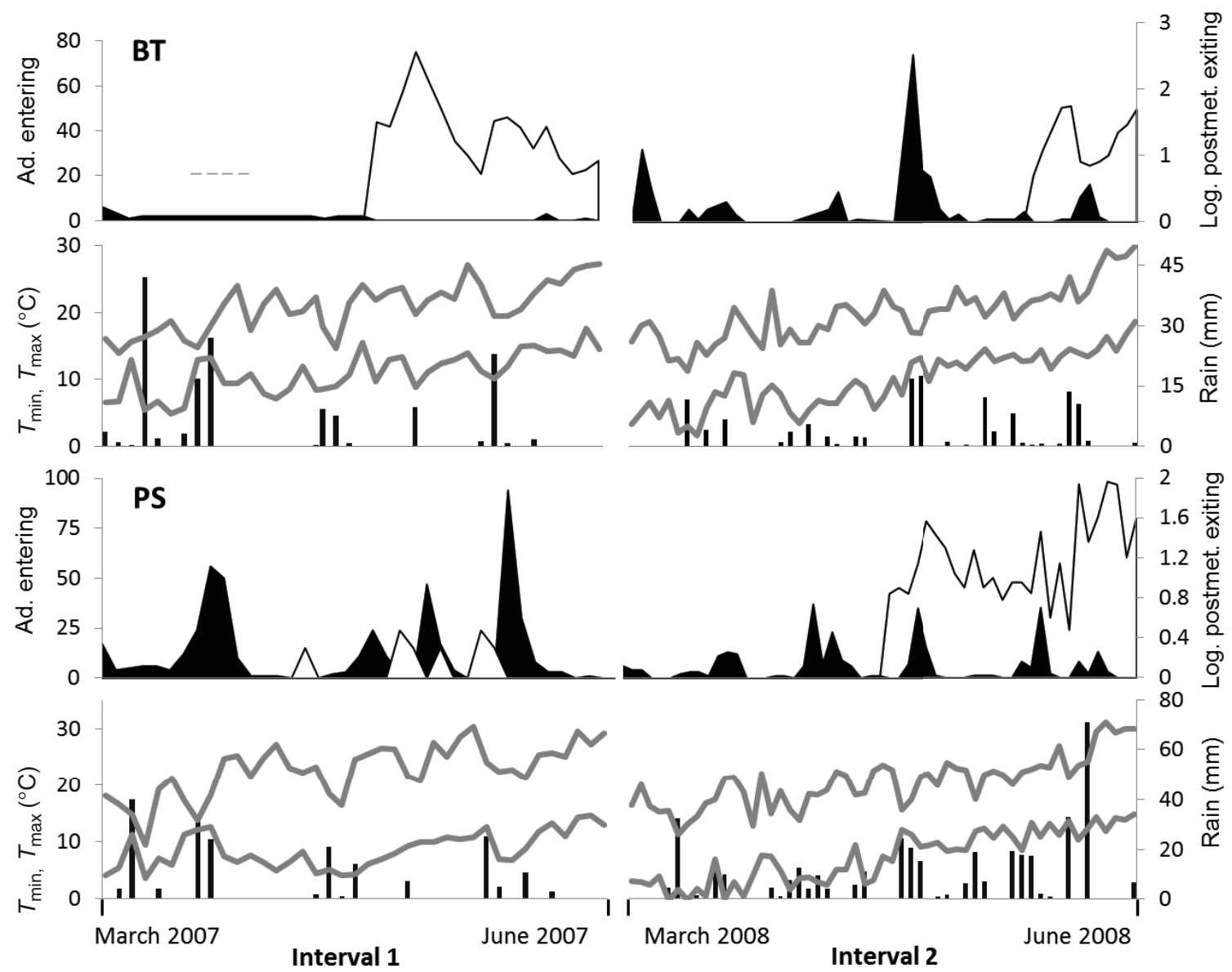

Fig. 4. Colonization dynamics of $B$. calamita and weather data. For the first and third panels, the number of adults entering the wetlands (Ad. entering) is shown in black, and the log of the number of post-metamorphic individuals exiting the wetlands (Log. post-met. exiting) is shown in white. For the second and fourth panels cumulative precipitation (Rain) is shown in black columns, and the minimum daily temperature $\left(T_{\min }\right)$ and maximum daily temperature $\left(T_{\max }\right)$ are shown by gray lines. During the dashed interval in BT (April 11-28, 2007), the pit-fall traps were only partially functional due to flooding.

\section{Colonization dynamics and reproductive success of $B$. calamita in man-made MTPs}

During both intervals, the number of adult $B$. calamita individuals entering the wetland and post-metamorphic individuals exiting the wetland were correlated to meteorological variables (Fig. 4). At the beginning of both intervals, adults were already being captured in an irregular pattern that generally followed rain events. For both BT and PS, there was a positive significant correlation 
Table 4. Spearman non-parametric correlations $(\rho)$ between the colonization variables of $B$. calamita (number of adults entering and number of post-metamorphic individuals exiting the wetland) and rain or temperature data. (Rain, 2 days cumulative precipitation; $T_{\min }$, minimum daily temperature; $T_{\max }$, maximum daily temperature). ns, $P>0.05 ; *, P<0.01$.

\begin{tabular}{lcccc}
\hline & & & & PS \\
\cline { 2 - 5 } & Ad. entering & Post-met. exiting & Ad. entering & Post-met. exiting \\
\hline Rain & $+0.457(*)$ & $-0.095(\mathrm{~ns})$ & $+0.182(*)$ & $+0.040(\mathrm{~ns})$ \\
$T_{\min }$ & $+0.051(\mathrm{~ns})$ & $+0.567(*)$ & $+0.168(*)$ & $+0.440(*)$ \\
$T_{\max }$ & $-0.291(*)$ & $+0.600(*)$ & $+0.042(\mathrm{~ns})$ & $+0.313(*)$ \\
\hline
\end{tabular}

Table 5. Sex and site effect on the mean recapture rate per adult, the maximum recapture rate for adults, the mean number of days spent in the wetland and the mean reproductive cost. These three parameters were tested by means of ANOVA, both by site (BT/ PS) and by sex (males/females) factors. ns, $P>0.05, * P<0.05, * * P<0.001$.

\begin{tabular}{|c|c|c|c|c|c|c|c|c|c|c|}
\hline & \multicolumn{2}{|c|}{$\mathrm{BT}$} & \multicolumn{2}{|c|}{ Sex effect } & \multicolumn{2}{|c|}{ PS } & \multicolumn{2}{|c|}{ Sex effect } & \multicolumn{2}{|c|}{ Site effect } \\
\hline & Males & Females & $F$ & $P$ & Males & Females & $F$ & $\bar{P}$ & $F$ & $P$ \\
\hline $\begin{array}{l}\text { Individuals marked/ } \\
\text { recaptured }\end{array}$ & $118 / 104$ & $68 / 52$ & & & $131 / 110$ & $228 / 178$ & & & & \\
\hline Mean recaptures (max.) & $1.41(6)$ & $1.21(3)$ & 15.03 & $* *$ & $2.12(8)$ & $1.40(3)$ & 85.82 & $* *$ & 3.54 & ns \\
\hline $\begin{array}{l}\text { Mean days in the } \\
\text { wetland } \pm \mathrm{SE}\end{array}$ & $19.43 \pm 2.7$ & $9.17 \pm 2.4$ & 5.23 & $*$ & $23.02 \pm 2.4$ & $11.50 \pm 1.4$ & 21.27 & $* *$ & 0.019 & ns \\
\hline $\begin{array}{l}\text { Mean weight } \% \\
\text { when exiting } \pm \mathrm{SE}\end{array}$ & $96.12 \pm 1.3$ & $81.63 \pm 2.3$ & 32.93 & $* *$ & $94.95 \pm 2.9$ & $85.45 \pm 1.8$ & 9.34 & $* *$ & 1.22 & ns \\
\hline
\end{tabular}

between the number of adults entering the wetland and the cumulative precipitation (Tab. 4). Minimum daily temperature had a positive significant correlation with the number of entering adults only in PS. By contrast, maximum daily temperature had a negative significant correlation with the number of entering adults in BT. Postmetamorphic individuals appeared for the first time during weeks 7-9 and dominated the second half of both intervals at both sites. While the number of post-metamorphic individuals exiting the wetland was not significantly affected by precipitation at either site, both minimum daily temperature and maximum daily temperature had significant positive correlations to the number of post-metamorphic individuals exiting the wetland in both sites (Tab. 4).

GLMM confirmed that the number of $B$. calamita adults varied significantly between sites $\left(F_{1,3}=3.993\right.$, $P<0.05)$, intervals $\left(F_{1,3}=75.841, P<0.001\right)$ and weeks $\left(F_{14,16}=35.165, P<0.001\right.$; Fig. 5$)$. Although the number of adults entering the wetland was higher in PS than in BT, the number of post-metamorphic individuals exiting the wetland was higher in BT than in PS $\left(F_{1,42}=5179.71\right.$, $P<0.001)$. In both sites, there was a higher number of post-metamorphic individuals caught in the traps in interval 1 compared to interval $2\left(F_{1,42}=7.392, P<0.01\right)$. Adults had irregular movements throughout the intervals. In contrast, post-metamorphic individuals consistently exited the wetlands beginning at the seventh week $\left(F_{9,50}=7998.84, P<0.001\right)$.

Using toe clips, we marked $186 \mathrm{~B}$. calamita in BT and 359 in PS (Tab. 5). In both sites, males were significantly more likely to be recaptured than females. Additionally, the maximum number of times that an individual was recaptured was higher for males than for females. Males spent approximately twice as much time in the wetland compared to females. In spite of the shorter time in the wetland, females lost a higher proportion of weight

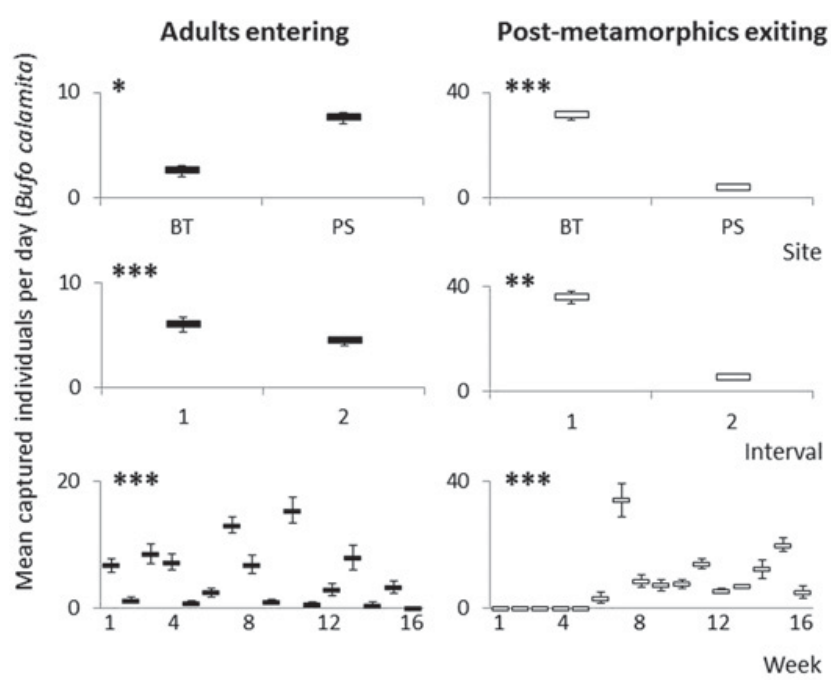

Fig. 5. GLMM results of the spatial and temporal variability of $B$. calamita colonization. Site, interval and week were fixed effects, whereas sampling day was set as a random factor. $* P<0.05, * * P<0.01, * * * P<0.001$.

(15-18\% of their pre-reproductive weight) during breeding compared to males $(4-5 \%$ of their pre-reproductive weight).

\section{Discussion}

\section{Local amphibian diversity and colonization of man-made wetlands}

Local diversity levels differed between BT and PS areas, a result coherent with previous studies in both areas (Pleguezuelos et al., 2002; Boix et al., 2004a). Strong 
anthropogenic influences such as intensive agriculture have been associated with habitat fragmentation, which in turn controls the viability of regional amphibian populations (Lehtinen et al., 1999; Beja and Alcazar, 2003; Cushman, 2006; Fischer and Lindenmayer, 2007). This could have caused in BT the absence of urodeles, a group with low dispersion rates and short maximal dispersal distances (Smith and Green, 2005). Furthermore, cultivation and nutrient enrichment has probably affected the natural wetlands in BT watershed, as observed in other regions of the Iberian Peninsula (García-Muñoz et al., 2010). Negative effects of agricultural intensification on micro- and macrofaunal assemblages have already been described (Beja and Alcazar, 2003; Rohr and Crumrine, 2005; Peltzer et al., 2006). Particularly, the impact of pesticides on water quality has been confirmed both regionally (e.g., Hildebrandt et al., 2008) and locally, at nearby wetlands (e.g., López-Flores et al., 2003; Salvadó et al., 2006). Hence, despite having no data from the studied natural and reference wetlands, we believe that this fact could explain why in BT some species were using the man-made MTPs, rainwater-fed, instead of the natural ones, which were often connected to managed ecosystems such as rice fields.

Key factors that influence the colonization of a new or restored pond include the regional amphibian community and the size and isolation of the pond (e.g., Laan and Verboom, 1990; Lehtinen and Galatowitsch, 2001; Oertli et al., 2002). In our case, high connectivity to other local bodies of water led to the high proportion of local species that arrived to the new wetlands during the first hydroperiod. Compared to amphibian colonization and reproduction in new wetlands in Europe (Tab. 6), PS had not only the highest regional diversity for potential colonization (11 species) but also a remarkably high percentage of successful colonization $(82 \%)$. Moreover, most of the species in both sites also reproduced in the new wetlands within the first (60\% in BT, $55 \%$ in PS) or second ( $80 \%$ in BT, $73 \%$ in PS) year. This proportion will likely evolve in subsequent years, yet it is remarkably high compared to other short-term colonization studies in Europe (Laan and Verboom, 1990; Lesbarrères et al., 2010). These studies have found little or no reproduction in new or restored wetlands, whereas other studies have found colonization and reproduction rates similar to what we show here by studying older wetlands (Beebee, 1997; Baker and Halliday, 1999) or by including many more ( > 100) bodies of water (Stumpel and van der Voet, 1998; Rannap et al., 2009). Accordingly, amphibian colonization studies of North American new or restored wetlands have shown similar results for a wide range of potential colonizing species (Tab. 6), supporting our finding that important colonizers arrive at the new or restored wetland within the first 2 years (e.g., Perry et al., 1996; Lehtinen and Galatowitsch, 2001; Pechmann et al., 2001; Stevens et al., 2002). Unlike what we found, however, only one case of North American colonization detected more than $50 \%$ of these local species reproducing by the second year (Vasconcelos and Calhoun, 2006).
Although the colonization of the new wetlands included individuals from most local species of the amphibian community, many species were present in low numbers ( $<50$ individuals). These low numbers might be related to limited dispersal abilities of some species (Smith and Green, 2005 and references therein) and a high site fidelity (e.g., Cushman, 2006). Also, low counts could be biased by our capture methods that probably underestimate the abundance of climbing species such as H. meridionalis (Dodd, 1992). The two most abundant species, D. pictus and $B$. calamita, are known to be pioneering and opportunistic and to have wide dispersal ranges (Sinsch, 1988; Miaud et al., 2000; Boix et al., 2004b; Montori et al., 2007), which appear to have helped them to take advantage of temporary newly created wetlands.

\section{Colonization dynamics and reproductive success of $B$. calamita}

The annual biological cycle of $B$. calamita is characteristically discontinuous, with peaks in activity related to the weather (Tejedo and Reques, 1997; Brooke et al., 2000). Here, we confirmed the known role of temperature and precipitation on the breeding phenology of $B$. calamita (Banks and Beebee, 1986; Sinsch, 1988). In BT, where the average rainfall was lower than in PS, the movement of adult $B$. calamita had a stronger correlation with rain events. Low minimum temperatures and high maximum temperatures led to a reduction in adult movement. In BT, a sea-regulated microclimate, the temperature range was narrow. Due to inactivity on hot days, maximum temperature was inversely correlated with adult movement. In contrast, without the sea-regulated microclimate, PS exhibited much lower minimum temperatures, which led to reduced adult activity. The activity of exiting postmetamorphic individuals was correlated with both the minimum and maximum temperatures, likely due to the rapid larval development of B. calamita (e.g., Álvarez and Salvador, 1984; Boomsma and Arntzen, 1985) and the quick-response effect of water temperature on the metamorphosing larvae. Evaporation of these shallow wetlands increases the density and the intraspecific competition, leading to the acceleration of metamorphosis (Tejedo and Reques, 1994; Newman, 1998).

It generally takes 2-5 years for $B$. calamita individuals to reach sexual maturity (Denton and Beebee, 1993; García-París et al., 2004). Although stressed populations can show secondary sexual characteristics during the first year of life, which would lead to faster reproduction (unpublished data on $B$. calamita populations of the Cantabrican Coast, Spain), we did not observe such early reproduction in either BT or PS. Consistent with other studies (Pough et al., 1992; Joly and Grolet, 1996), the reproductive investment for females was much higher than for males. B. calamita males invested more time in the wetland and exhibited more movement into and out of the wetland, both of which have been related to male mating success (i.e., Arak, 1988). B. calamita population 


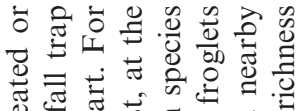

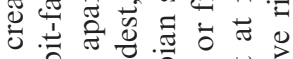

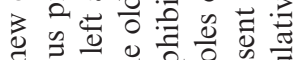

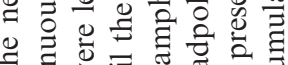
男

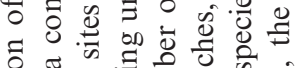

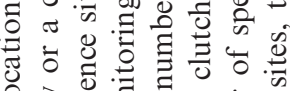

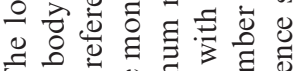

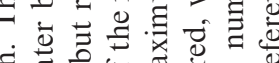
일 悹吅 궁

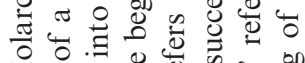
工

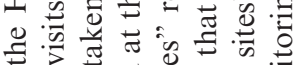

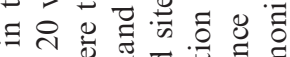
㻤

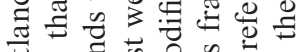

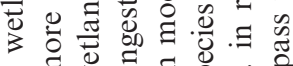

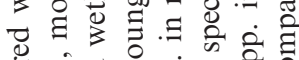

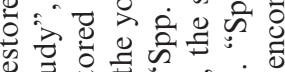

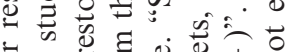
50 을

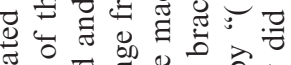

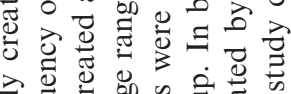

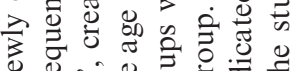

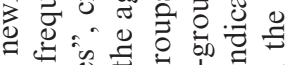

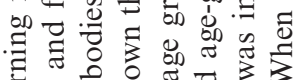

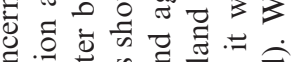

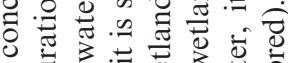

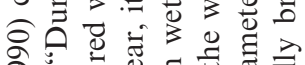
o 舟语請

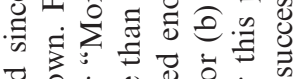

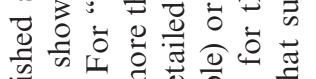

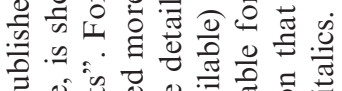

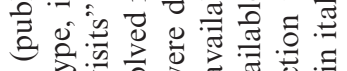

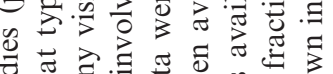

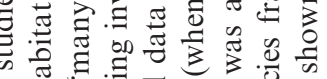

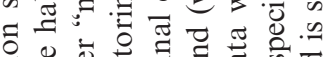

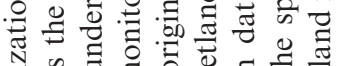
s.

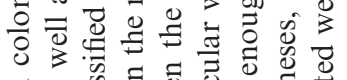

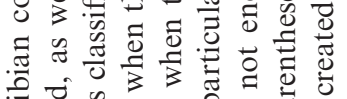

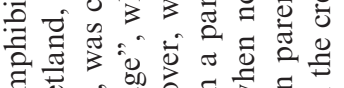

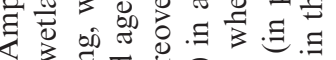

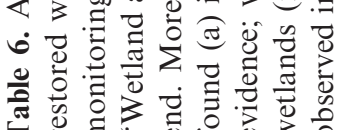

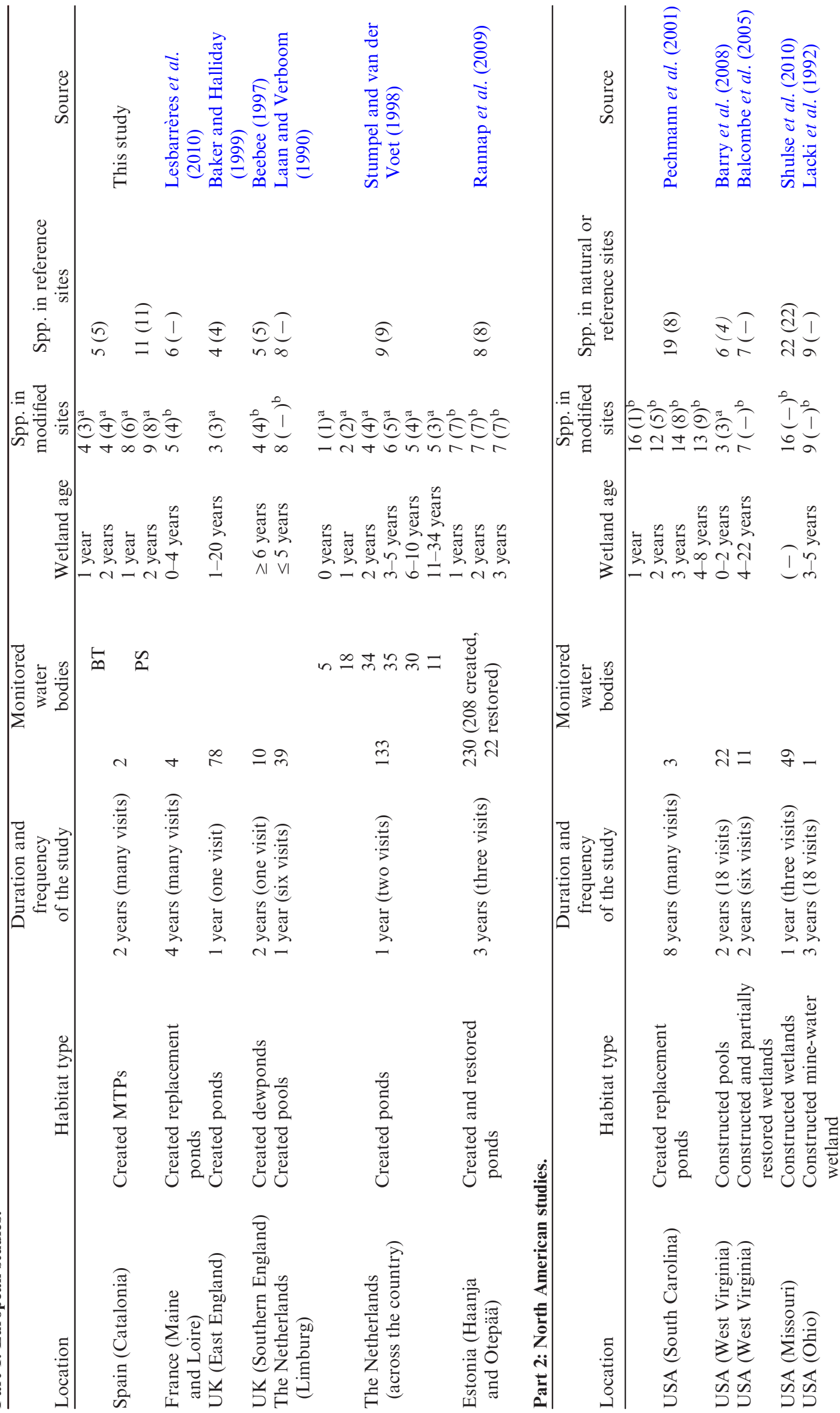




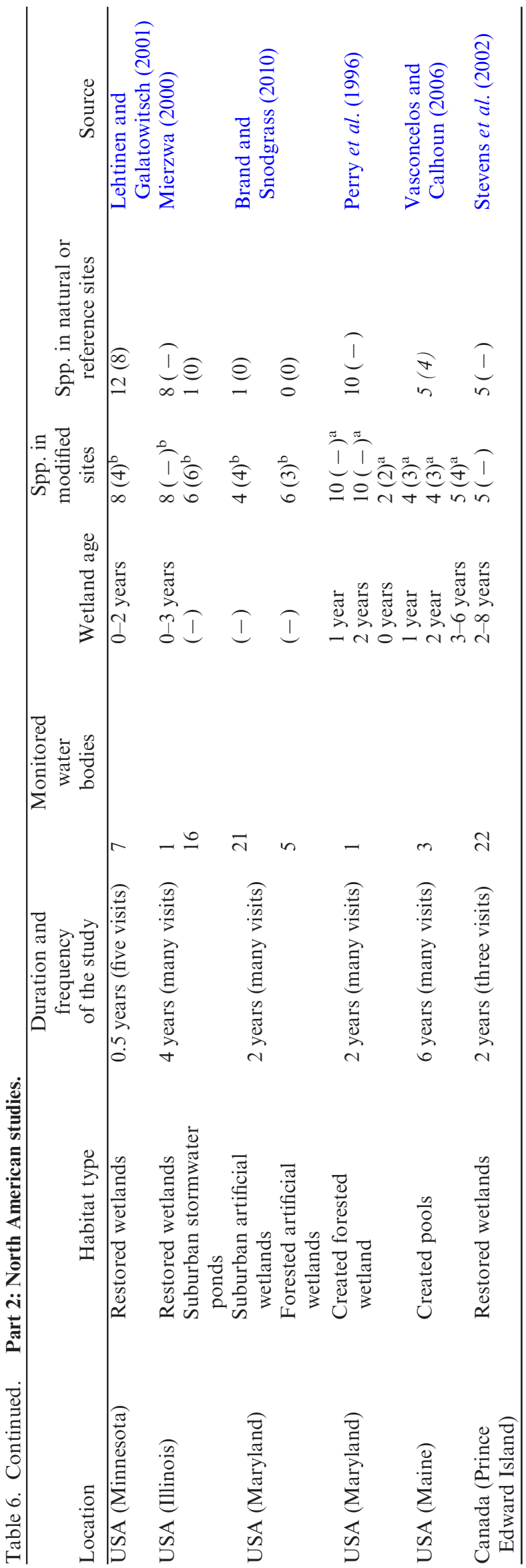

variability has also been described in long-term studies of natural systems (Bragg, 1960). In this study, this natural variability could be mixed with effects such as the changing invertebrate community of newly created wetlands (Ruhí et al., 2009) and the hydrological unpredictability of Mediterranean ecosystems (Álvarez-Cobelas et al., 2005; Gascón et al., 2007), also observed in these manmade MTPs.

\section{Conservation interest of man-made MTPs}

It is well accepted that newly created wetlands should be assessed with deep, qualitative and long-term studies (Zedler and Callaway, 1999; Pechmann et al., 2001; Petranka et al., 2003, 2007; Vasconcelos and Calhoun, 2006). However, this study provided evidence of the benefits of artificial MTPs for amphibian conservation already within a short-term period. Other short-term studies in recovered wetlands have shown that anuran densities can be similar to or even higher than the densities in natural wetlands (e.g., Balcombe et al., 2005; Brand and Snodgrass, 2010). Hence, in such situations artificial wetlands may help recover declining populations of threatened species (Rannap et al., 2009).

$B$. calamita is a species protected by Spanish and European laws that has lately suffered a population decline (Beja et al., 2009). The creation of these and other MTPs would likely benefit $B$. calamita populations in the Mediterranean region, as has already been observed in the United Kingdom (Denton et al., 1997). In a broader sense, although we show that artificial MTPs created new habitat mainly for local amphibian pioneering or opportunistic species, our results imply that effects of man-made MTPs need to be further evaluated. We suggest that there is enough evidence to regard these man-made systems as a key tool for aquatic biodiversity conservation even in short-term perspectives, a fact that could partly compensate for the loss of natural temporary ponds in the Mediterranean region.

Acknowledgements. This research was supported by LIFE 04 NAT/ES/000059 project, a PhD FPU grant and a Scientific Research grant (CGL2008 05778/BOS) from the Spanish Government, and the economic support of AGAUR, Government of Catalonia. We also would like to thank Emys Foundation, Gavarres Factory School, Aranzadi Science Society and Torroella de Montgrí Town Hall for their contributions to this work.

\section{References}

Álvarez J. and Salvador A., 1984. Cría de anuros en la laguna de Chozas de Arriba (León). Mediterranea, 7, 27-48.

Álvarez-Cobelas M.A., Rojo C. and Angeler D.G., 2005. Mediterranean limnology: current status, gaps and the future. J. Limnol., 64, 13-29. 
Arak A., 1988. Female mate selection in the natterjack toad: active choice or passive atraction?Behav. Ecol. Sociobiol., 22, 317-327.

Baker J.M.R. and Halliday T.R., 1999. Amphibian colonization of new ponds in an agricultural landscape. Herpetolog. J., 9, 55-63.

Balcombe C.K., Anderson J.T., Fortney R.H. and Kordek W.S., 2005. Wildlife use of mitigation and reference wetlands in West Virginia. Ecol. Eng., 25, 85-99.

Banks B. and Beebee T.J.C., 1986. Climatic effects on calling and spawning of the Natterjack toad Bufo calamita: discriminant analyses and applications for conservation monitoring. Biol. Conserv., 36, 339-350.

Barry D.S., Pauley T.K. and Maerz J.C., 2008. Amphibian use of man-made pools on clear-cuts in the Allegheny Mountains of West Virginia, USA. Appl. Herpetol., 5, 121-128.

Beebee T.J.C., 1997. Changes in dewpond numbers and amphibian diversity over 20 years on chalk downland in Sussex, England. Biol. Conserv., 81, 215-219.

Beebee T.J.C. and Griffiths R.A., 2005. The amphibian decline crisis: a watershed for conservation biology?Biol. Conserv., 125, 271-285.

Beja P. and Alcazar R., 2003. Conservation of Mediterranean temporary ponds under agricultural intensification: an evaluation using amphibians. Biol. Conserv., 114, 317-326.

Beja P., Kuzmin S., Beebee T., Denoël M., Schmidt B., Tarkhnishvili D., Ananjeva N., Orlov N., Nyström P., Ogrodowczyk A., Ogielska M., Bosch J., Miaud C., Tejedo M., Lizana M. and Martínez-Solano I., 2009. Epidalea calamita. In: IUCN 2011. Red List of Threatened Species. Version 2011.2. <www.iucnredlist.org > Downloaded on 24 January 2012.

Boix D., Franch M. and Mascort R., 2004a. Els amfibis i rèptils del Baix Ter. In: Quintana X.D. and Marí M. (eds.), Els Aiguamolls del Baix Ter, Monografia dels Papers del Montgrí, Vol. 23: Papers del Montgrí, Torroella de Montgrí, Spain, 86-110.

Boix D., Sala J., Quintana X.D. and Moreno-Amich R., 2004b. Succession of the animal community in a Mediterranean temporary pond. J. N. Am. Benthol. Soc., 23, 29-49.

Boix D., Sala J. and Moreno-Amich R., 2001. The faunal composition of Espolla pond (NE Iberian peninsula): the neglected biodiversity of temporary waters. Wetlands, 21, $577-592$.

Boomsma J.J. and Arntzen J.W., 1985. Abundance, growth and feeding of natterjack toads (Bufo calamita) in a 4-year-old artificial habitat. J. Appl. Ecol., 22, 395-405.

Bragg A.N., 1960. Population fluctuation in the amphibian fauna of Cleveland County, Oklahoma during the past twenty-five years. Southwest Nat., 5, 165-169.

Brand A.B. and Snodgrass J.W., 2010. Value of artificial habitats for amphibian reproduction in altered landscapes. Conserv. Biol., 24, 295-301.

Brooke P.N., Alford R.A. and Schwarzkopf L., 2000. Environmental and social factors influence chorusing behaviour in a tropical frog: examining various temporal and spatial scales. Behav. Ecol. Sociobiol., 49, 79-87.

Brown P.H. and Lant C.L., 1999. The effect of wetland mitigation banking on the achievement of no-net-loss. Environ. Manage., 23, 333-345.

Clarke K.R., 1993. Non-parametric multivariate analyses of changes in community structure. Aust. J. Ecol., 18, 117-143.
Comín F.A. (ed.), 2010. Ecological Restoration. A Global Challenge, Cambridge University Press, Cambridge, 318 p.

Cox N.A., Chanson J.S. and Stuart S.N. (eds.), 2006. The Status and Distribution of Reptiles and Amphibians of the Mediterranean Basin, IUCN, Gland, Switzerland and Cambridge, $42 \mathrm{p}$.

Crawley M., 2002. Statistical Computing: An Introduction to Data Analysis Using S-Plus, Chichester, 772 p.

Cushman S.A., 2006. Effects of habitat loss and fragmentation on amphibians: a review and prospectus. Biol. Conserv., 128, 231-240.

Denton J.S. and Beebee T.C.J., 1993. Density-related features of Natterjack toad (Bufo calamita) populations in Britain. J. Zool., 229, 105-119.

Denton J.S., Hitchings S.P., Beebee T.J.C. and Gent A., 1997. A recovery program for the Natterjack toad (Bufo calamita) in Britain. Conserv. Biol., 11, 1329-1338.

Díaz-Paniagua C., Fernández-Zamudio R., Florencio M., García-Murillo P., Gómez-Rodríguez C., Portheault A., Serrano L. and Siljeström P., 2010. Temporay ponds from Doñana National Park: a system of natural habitats for the preservation of aquatic flora and fauna. Limnetica, 29, 41-58.

Dodd C.K., 1992. Biological diversity of a temporary pond herpetofauna in north Florida sandhills. Biodivers. Conserv., $1,125-142$.

Donnelly M.A., Guyer C., Juterbock J.E. and Alford R., 1994. Techniques for marking amphibians. In: Heyer W.R., Donnelly M.A., McDiarmid R.W., Hayek L.-A.C. and Foster M.S. (eds.), Measuring and Monitoring Biological Diversity. Standard Methods for Amphibians, Smithsonian Institution Press, Washington, DC, 277-284.

Fischer J. and Lindenmayer D.B., 2007. Landscape modification and habitat fragmentation: a synthesis. Global Ecol. Biogeogr., 16, 265-280.

García-Muñoz E., Gilbert J., Parra G. and Guerrero F., 2010. Wetlands classification for amphibian conservation in Mediterranean landscapes. Biodivers. Conserv., 19, 901-911.

García-París M., Montori A. and Herrero P. (eds.), 2004. Amphibia, Museo Nacional de Ciencias Naturales and Consejo Superior de Investigaciones Científicas, Madrid, $639 \mathrm{p}$.

Gascón S., Boix D., Sala J. and Quintana X.D., 2007. Changes on macrobenthic fauna of a mediterranean salt marsh (Empordà wetlands, NE iberian peninsula) after a severe drought, with special emphasis on the Corophium orientale population. Vie Milieu, 57, 10.

Gibbons J.W., Winne C.T., Scott D.E., Willson J.D., Glaudas X., Andrews K.M., Todd B.D., Fedewa L.A., Wilkinson L., Tsaliagos R.N., Harper S.J., Greene J.L., Tuberville T.D., Metts B.S., Dorcas M.E., Nestor J.P., Young C.A., Akre T., Reed R.N., Buhlmann K.A., Norman J., Croshaw D.A., Hagen C. and Rothermel B.B., 2006. Remarkable amphibian biomass and abundance in an isolated wetland: implications for wetland conservation. Conserv. Biol., 20, 1457-1465.

Grasshoff K., Kremling K. and Ehrhardt M., 1983. Methods of Seawater Analysis, Verlag Chemie, Weinheim, 419 p.

Grillas P., Gauthier P., Yavercovski N. and Perennou C. (eds.), 2004. Mediterranean Temporary Pools, Station Biologique de la Tour du Valat, Arles, 118 p.

Hildebrandt A., Guillamón M., Lacorte S., Tauler R. and Barceló D., 2008. Impact of pesticides used in agriculture and 
vineyards to surface and groundwater quality (North Spain). Water Res., 42, 3315-3326.

Houlahan J.E., Findlay C.S., Schmidt B.R., Meyer A.H. and Kuzmin S.L., 2000. Quantitative evidence for global amphibian population declines. Nature, 404, 752-755.

Jakob C., Poizat G., Veith M., Seitz A. and Crivelli A.J., 2003. Breeding phenology and larval distribution of amphibians in a Mediterranean pond network with unpredictable hydrology. Hydrobiologia, 499, 51-61.

Jeffries M., 1991. The ecology and conservation value of forestry ponds in Scotland, United Kingdom. Biol. Conserv., 58, 191211.

Joly P. and Grolet O., 1996. Colonization dynamics of new ponds, and the age structure of colonizing Alpine newts, Triturus alpestris. Acta Oecol., 17, 599-608.

Laan R. and Verboom B., 1990. Effects of pool size and isolation on amphibian communities. Biol. Conserv., 54, 251-262.

Lacki M., Hummer J. and Webster H., 1992. Mine-drainage treatment wetland as habitat for herptofaunal wildlife. Environ. Manage., 16, 513-520.

Lehtinen R.M. and Galatowitsch S.M., 2001. Colonization of restored wetlands by amphibians in Minnesota. Am. Midl. Nat., 145, 388-396.

Lehtinen R.M., Galatowitsch S.M. and Tester J., 1999. Consequences of habitat loss and fragmentation for wetland amphibian assemblages. Wetlands, 19, 1-12.

Lesbarrères D., Fowler M.S., Pagano A. and Lodé T., 2010. Recovery of anuran community diversity following habitat replacement. J. Appl. Ecol., 47, 148-156.

López-Flores R.O., Quintana X.D., Salvadó V., Hidalgo M., Sala L. and Moreno-Amich R., 2003. Comparison of nutrient and contaminant fluxes in two areas with different hydrological regimes (Empordà Wetlands, NE Spain). Water Res., 37, 3034-3046.

Miaud C., Sanuy D. and Avrillier J.-N., 2000. Terrestrial movements of the natterjack toad Bufo calamita (Amphibia, Anura) in a semi-arid, agricultural landscape. Amphib. Reptil., 21, 357-369.

Mierzwa K.S., 2000. Wetland mitigation and amphibians: preliminary observations at a Southwestern Illinois bottomland hardwood forest restoration site. J. Iowa Acad. Sci., 107, 191-194.

Mitsch W.J. and Wilson R.F., 1996. Improving the success of wetland creation and restoration with know-how, time, and self-design. Ecol. Appl., 6, 77-83.

Montori A., Llorente G.A., Richter-Boix A., Villero D., Franch M. and Garriga N., 2007. Colonización y efectos potenciales de la especie invasora Discoglossus pictus sobre las especies nativas. Munibe, 25, 14-27.

Newman R.A., 1998. Ecological constraints on amphibian metamorphosis: interactions of temperature and larval density with responses to changing food level. Oecologia, 115, 9-16.

Oertli B., Auderset Joye D., Castella E., Juge R., Cambin D. and Lachavanne J.-B., 2002. Does size matter? The relationship between pond area and biodiversity. Biol. Conserv., 104, 59-70.

Oertli B., Biggs J., Céréghino R., Grillas P., Joly P. and Lachavanne J.-B., 2005. Conservation and monitoring of pond biodiversity: introduction. Aquat. Conserv.: Mar. Freshwat. Ecosyst., 15, 535-540.

Pearman P.B., Velasco A.M. and López A., 1995. Tropical amphibian monitoring: a comparison of methods for detecting inter-site variation in species' composition. Herpetologica, 51, 325-337.

Pechmann J., Estes R., Scott D. and Gibbons J., 2001. Amphibian colonization and use of ponds created for trial mitigation of wetland loss. Wetlands, 21, 93-111.

Peltzer P., Lajmanovich R., Attademo A. and Beltzer A., 2006. Diversity of anurans across agricultural ponds in argentina. Biodivers. Conserv., 15, 3499-3513.

Perry M.C., Sibrel C.B. and Gough G.A., 1996. Wetlands mitigation: partnership between an electric power company and a federal wildlife refuge. Environ. Manage., 20, 933-939.

Petranka J., Kennedy C. and Murray S., 2003. Response of amphibians to restoration of a southern Appalachian wetland: a long-term analysis of community dynamics. Wetlands, 23, 1030-1042.

Petranka J.W., Harp E.M., Holbrook C.T. and Hamel J.A., 2007. Long-term persistence of amphibian populations in a restored wetland complex. Biol. Conserv., 138, 371-380.

Pleguezuelos J.M., Márquez R. and Lizana M., 2002. Atlas y libro rojo de los anfibios y reptiles de España, Dirección General de la Conservación de la Naturaleza, Asociación Herpetológica Española, Madrid, 588 p.

Pough F.H., Magnusson W.E., Ryan M.J., Wells K.D. and Taigent T.L., 1992. Energetics and locomotion: behavioral energetics. In: Feder M.E. and Burggren W.W. (eds.), Environmental Physiology of the Amphibians, University of Chicago Press, Chicago, 395-436.

Rannap R., Lõhmus A. and Briggs L., 2009. Restoring ponds for amphibians: a success story. Hydrobiologia, 634, 87-95.

Rohr J.R. and Crumrine P.W., 2005. Effects of an herbicide and an insecticide on pond community structure and processes. Ecol. Appl., 15, 1135-1147.

Ruhí A., Boix D., Sala J., Gascon S. and Quintana X.D., 2009. Spatial and temporal patterns of pioneer macrofauna in recently created ponds: taxonomic and functional approaches. Hydrobiologia, 634, 137-151.

Sala J., Gascón S., Boix D., Gesti J. and Quintana X.D., 2004. Proposal of a rapid methodology to assess the conservation status of Mediterranean wetlands and its application in Catalunya. Arch. Sci., 57, 141-152.

Salvadó V., Quintana X. and Hidalgo M., 2006. Monitoring of nutrients, pesticides, and metals in waters, sediments, and fish of a wetland. Arch. Environ. Contam. Toxicol., 51, 377-386.

Shulse C., Semlitsch R., Trauth K. and Williams A., 2010. Influences of design and landscape placement parameters on amphibian abundance in constructed wetlands. Wetlands, 30 , 915-928.

Sinsch U., 1988. Temporal spacing of breeding activity in the natterjack toad, Bufo calamita. Oecologia, 76, 399-407.

Smith M.A. and Green D.M., 2005. Dispersal and the metapopulation paradigm in amphibian ecology and conservation: are all amphibian populations metapopulations?Ecography, $28,110-128$.

Stevens C., Diamond A. and Gabor T., 2002. Anuran call surveys on small wetlands in Prince Edward Island, Canada restored by dredging of sediments. Wetlands, 22, 90-99.

Stuart S.N., Chanson J.S., Cox N.A., Young B.E., Rodrigues A.S.L., Fischman D.L. and Waller R.W., 2004. Status and trends of amphibian declines and extinctions worldwide. Science, 306, 1783-1786. 
Stumpel A.H.P. and van der Voet H., 1998. Characterizing the suitability of new ponds for amphibians. Amphib. Reptil., 19, 125-142.

Tejedo M. and Reques R., 1994. Plasticity in metamorphic traits of natterjack tadpoles: the interactive effects of density and pond duration. Oikos, 71, 295-304.

Tejedo M. and Reques R., 1997. Bufo calamita. In: Pleguezuelos J.M. (ed.), Distribución y biogeografía de los anfibios y reptiles en España y Portugal, Asociación Herpetológica Española y Universidad de Granada, Granada, 155-157.

Vasconcelos D. and Calhoun A., 2006. Monitoring created seasonal pools for functional success: a six-year case study of amphibian responses, Sears Island, Maine, USA. Wetlands, 26, 992-1003.

Wake D.B. and Vredenburg V.T., 2008. Are we in the midst of the sixth mass extinction? A view from the world of amphibians. Proc. Natl. Acad. Sci. U.S.A., 105, 11466-11473.

Zacharias I., Dimitriou E., Dekker A. and Dorsman E., 2007. Overview of temporary ponds in the Mediterranean region: threats, management and conservation issues. J. Environ. Biol., 28, 1-9.

Zedler J.B. and Callaway J.C., 1999. Tracking wetland restoration: do mitigation sites follow desired trajectories? Restor. Ecol., 7, 69-73. 